\title{
Robert Hood (1797-1821)
}

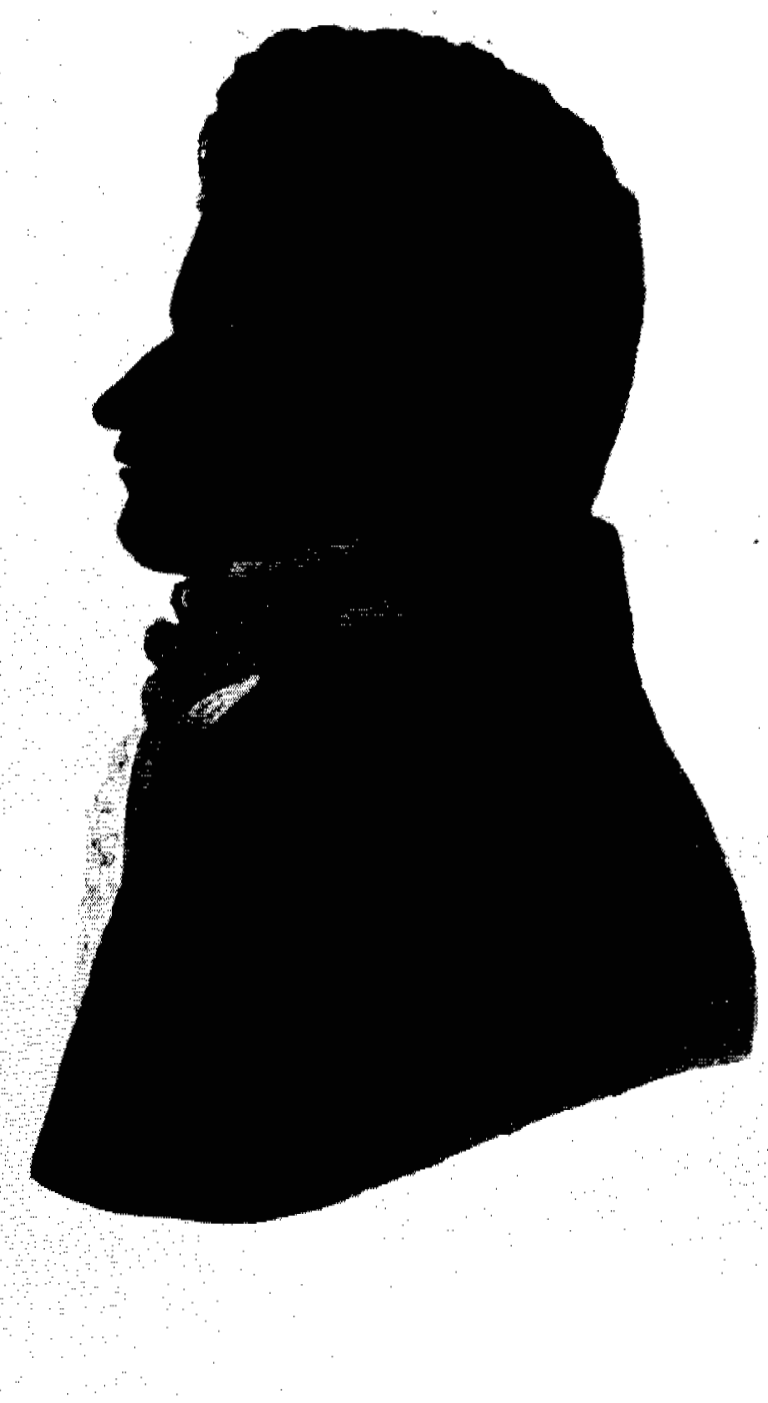

Robert Hood was a junior officer with the badly timed, inadequately supplied first Arctic Land Expedition led by John Franklin in 1819-22. Hood made a major contribution to the expedition's incredibly accurate mapping of over 600 miles of coastline, which, in the words of L.H. Neatby, "put a roof on the map of Canada." Hood was the first to prove the action of the aurora borealis on the compass needle and to show that the aurora was an electrical phenomenon. He also made important contributions to our knowledge of terrestrial magnetism, climatology, anthropology, and natural history. Hood's journal, a less formal and more sprightly account of the journey than Franklin's, was published with many of his watercolour paintings 153 years after his tragic death on the Barrenlands.
Robert Hood, the second son of the Reverend Richard Hood, LL.D., was born in 1797 and educated in Bury, Lancashire, eight miles north of Manchester. At fourteen he became a midshipman and continued his education on board ship.

The Franklin expedition, with John Richardson as surgeonnaturalist, sailed from Gravesend in May 1819 in Hudson's Bay Company ships. Before the advent of photography, one or more illustrators were customarily attached to such an expedition; the Admiraity chose Robert Hood and George Back as midshipmen because of their artistic abilities and their scientific proficiencies. Richardson and Hood spent the first winter at Cumberland House, where Hood painted Indians, animals, 
and birds, including five bird forms not yet described to science.

Throughout the journey, Hood was the primary surveyor and draughtsman. Whether on foot or in a canoe, Hood plotted accurately as many as 33 changes of course in a single day. His sketches and paintings, executed 27 years before those of Paul Kane, were done under trying circumstances; sometimes his brush would freeze to the paper.

It is a miracle that Hood's exquisite watercolours from Cumberland House arrived at York Factory in such good condition. No doubt they were well wrapped in beaver skins and well protected from the spray during the negotiation of numerous rapids. The paintings were conveyed by Governor William Williams of the Hudson's Bay Company, who that year took the longer, more difficult Minago route to avoid capture by rival North West Company men who were lying in wait for him at Grand Rapids.

Some of Hood's scenes were used to illustrate Franklin's 1823 journal. Comparison with the original paintings, however, shows that the engraver took considerable liberties. Hood realistically portrayed the men in their soiled and somewhat ragged garb, whereas the engraver depicted them in clean and tidy uniforms. These paintings and Hood's original journal were found, well protected from light, in the attic of a coachhouse in Tipperary, Ireland, when Hood's sister's granddaughter died there in 1933.

At Fort Enterprise, their winter quarters in 1820-21, Hood and Back were rivals for the favour of an attractive sixteenyear-old Copper Indian girl, Greenstockings. This rivalry, which led to the two midshipmen planning a duel, may have contributed to Franklin's decision to send Back on a remark- able 1100-mile snowshoe trip to and from Fort Chipewyan in midwinter. In any event, Hood won the maiden's approval, and some time after his death, Greenstockings bore an infant daughter, later listed in the official census as "orphaned daughter of Robert Hood, R.N."

The last entry in Hood's extant journal is for 15 September 1820. The extant journal of John Richardson begins at nearly the same time, with only eight days of overlap. The journals of all three subordinate officers, including Back's unpublished one, together offer a vivid portrayal of the fatigue and starvation suffered on the tragic return trek overland across the Barrens, after a successful summer of arctic exploration. No less than 11 of the 20 members of the party perished. Hood was within a few days of death from starvation when on 20 October 1821 , less than 30 miles from Fort Enterprise, his end was hastened by a bullet through the head fired by Michel Terohaute, one of the voyageurs. Richardson and Hepburn, his two remaining companions in the straggling rearward group, owed their survival in part to eating, knowingly or unknowingly, some human flesh and Hood's buffalo robe.

Hood contributed in full measure to the success of the first expedition before he paid the supreme sacrifice - and his journals and paintings remain one of the earliest and most vivid records of life in the Canadian North. Although his promising career was terminated prematurely, his memory is perpetuated by a flower, the moss phlox, Phlox hoodii, a sedge, Carex hoodii, the thirteen-striped ground squirrel, Citellus tridecemlineatus hoodii, and by the mighty Hood River that plunges over Wilberforce Falls before entering the Arctic Ocean.

\title{
FURTHER READINGS
}

FRANKLIN, JOHN. 1823. Narrative of a Journcy to the Shores of the Polar Sea in the Years 1819, 20, 21 and 22. London: John Murray.

Houston, C. STUART. (ed.). 1974. To the Arctic by Canoe, 1819-1821: The Journal and Paintings of Robert Hood, Midshipman with Franklin. Montreal: MçGill-Queen's University Press.

(ed.). In press. Arctic Ordeal: The Journal of John Richardson, SurgeonNaturalist with Franklin. Montreal: McGill-Qucen's University Press.

\author{
C. Stuart Houston \\ 863 University Drive \\ Saskatoon, Saskatchewan, Canada \\ S7N 0J8
}

